\title{
Pateo do Collegio, lugar de nascimento e memória: a reforma litúrgica realizada por Cláudio Pastro
}

HILDA SOUTO I e MÁRCIO LUIZ FER NANDES II

\section{Introdução}

ANÁLise feita neste artigo a respeito da reforma do espaço litúrgico em-
preendida na Igreja São José de Anchieta, em São Paulo, necessita ser
entendida dentro de um contexto histórico e eclesial.

Com base na tradição das primeiras comunidades cristãs, nas Escrituras Sagradas e nos documentos eclesiais e magisteriais, Claudio Pastro (1948-2016), ${ }^{1}$ artista convidado pelos superiores da Companhia de Jesus $^{2}$ para a elaboração do novo projeto interno da igreja em 2009, fundamentou seu trabalho em três grandes pilares para compor a reforma do espaço: o passado histórico do edifício, os ditames do Concílio Ecumênico Vaticano II e a crescente e viva comunidade que participa dos cultos dominicais, vinda de várias regiões do estado de São Paulo.

O edifício que conhecemos hoje, no centro da cidade de São Paulo, não é o original. Inaugurado em 1979, trata-se de uma réplica do que foi construído em 1556 e demolido no final do século XIX. O prédio atual não é tombado pelo patrimônio histórico e as peças remanescentes do antigo conjunto do altar-mor, sobretudo as colunas salomônicas do século XVII, foram restauradas e salvaguardadas no Museu da Companhia de Jesus.

\section{Princípios da teologia do espaço celebrativo}

Para muitas culturas e religiões com ritos e modos diferentes de expressar a fé, falar de um local de celebração pode sugerir espaços e elementos da natureza tais como montanha, gruta, árvore, nuvem etc., dependendo de como cada comunidade encara sua forma de reportar-se ao sagrado.

Para os cristãos, e especificamente para os católicos, tanto do rito oriental como ocidental, o problema do espaço onde a assembleia se reúne foi pensado, desde os primórdios do cristianismo, a partir da perspectiva teológica de que o templo em si não se constitui no lugar da presença de Deus, tal como vemos expresso no diálogo de Jesus com a Samaritana no capítulo IV do Evangelho de João. Por isso, o edifício material foi denominado de "domus ecclesiae" (Eusebio 
de Cesareia, 2000, VIII, 2, 1), ou seja, a morada onde a assembleia podia se reunir para a oração. Em sentido teológico, portanto, a "casa da Igreja" como edifício torna-se expressão daquela realidade comunitária que "prevalece sobre a realidade local físico-geográfica, arquitetônica" (Maldonado; Fernandez, 1990, p.176). O grande monge beneditino Odo Casel dizia que a Igreja revelava sua natureza mais profunda a partir das celebrações litúrgicas e advertia para o apego exclusivo aos elementos externos, como é o caso dos edifícios de pedra, esquecendo de que eles são símbolos que remetem à realidade do Mistério (Casel, 1965, p.343).

O edifício da Igreja Católica de Rito Romano, que é o objeto de estudo deste artigo, possui funções e necessidades que devem ser levadas em consideração quando se elabora um projeto arquitetônico e iconográfico. A existência de documentos eclesiais, originados a partir da vida da Igreja, traduz as necessidades de reformas estudadas à luz da tradição, mas sem se deixar engessar por ela. As construções arquitetônicas e os espaços internos do edifício cristão devem estar em consonância com o rito ali celebrado.

Como espaço litúrgico entende-se o local onde os cristãos se reúnem, com periodicidade, para celebrarem a fé que desejam viver e testemunhar, ouvindo a Palavra proclamada e comungando do pão eucarístico, mas também experimentando a comunhão que os une aos outros crentes. Assim, o conceito de espaço litúrgico como espaço vivente é fruto do amadurecimento teológico a respeito da celebração cristã. A natureza do culto celebrado é um tópico que merece atenção. Segundo Pastro (1999, p.43)

As artes do espetáculo e do esporte são autoexpressivas. Nessas artes o ator é o homem. A liturgia não é o âmbito em que vou desenvolver um papel. É a casa na qual sou hóspede. $\mathrm{O}$ ator do drama litúrgico não é o homem, mas o Homem-Deus, Jesus Cristo em pessoa. Sem essa visão de fé, a liturgia em nada difere de um penoso e estranho teatro que em nada justifica a Santa Missa cada domingo.

Segundo Frade (2007, p.105), o distanciamento que existia entre a Igreja e o mundo no início do século XX era tão evidente que isso repercutiu marcadamente no espaço arquitetônico e nas artes:

No interior das igrejas desse período estão presentes uma série de elementos devocionais, que em vez de introduzir os fiéis no mistério da salvação acabam tendo uma função de distração e de separação, distanciando-os de uma participação ativa na liturgia e fomentando piedades de cunho mais individual. É o caso da profusão - em alguns casos beirando o absurdo - de estátuas de santos, de altares laterais com uma índole mais devocional e da barreira arquitetônica proporcionada pela mesa de comunhão, que findava por separar ainda mais o presbitério da assembleia.

[...] Nesse contexto de afastamento da vida litúrgica e de fechamento à modernidade, nasce no início do século XX o Movimento Litúrgico, com o profundo desejo de retomar o verdadeiro espírito cristão presente na liturgia e na sua linguagem simbólica - inclua-se aqui a arquitetura religiosa. 
A intencionalidade teológica e pastoral do Movimento Litúrgico, por sua vez, frisou justamente a necessidade de proporcionar uma participação litúrgica mais ativa como forma de entrar profundamente no mistério. E foi exatamente este fenômeno dialógico e participativo que o Vaticano II reassumiu. No Brasil, um dos principais agentes promotores deste Movimento foi o beneditino D. Martinho Michler (1901-1969). ${ }^{3}$ A proposta mais contundente lançada pelo monge foi a celebração da missa versus populum, ou seja, voltada para o povo, uma novidade dentro do contexto do culto que era celebrado pelo presbítero de costas para o povo e em latim. Outro agente importante para a implementação das questões levantadas pelo Movimento Litúrgico foi D. Carlos Carmelo de Vasconcellos Motta (1890-1982), cardeal de São Paulo, que, com muita maestria, soube interferir e conduzir a Igreja local à abertura e à comunicação com o mundo externo, inclusive nas questões sociais, juntamente com D. Hélder Câmara (1909-1999). ${ }^{4}$

Como já dissemos, o Movimento Litúrgico antecedeu o Concílio Vaticano II e, na verdade, preparou o solo para que a Igreja católica recebesse as mudanças propostas pelos bispos conciliares. Para entender melhor as reformas, sobretudo litúrgicas, que aconteceram na Igreja e o que foi o Concílio Ecumênico Vaticano II é necessário ater-nos a um pouco de história.

Consagrado como maior evento católico do século XX, o Concílio Vaticano II foi convocado pelo Papa João XXIII e aberto oficialmente em 11 de outubro de 1962. O encerramento deu-se no papado de Paulo VI em 8 de dezembro de 1965. Foram quatro anos de grandes reflexões em que se plasmou o principal objetivo do Concílio: a renovação da Igreja, ou seja, segundo o Papa João XXIII, um "Novo Pentecostes". ${ }^{5}$ Um dos principais pontos de atualização deu-se na liturgia, que passou a ser celebrada de frente para ao povo e na língua vernácula, tornando-se assim uma celebração participativa tendo como centro o próprio Cristo. Para Triacca (1987, p.351, apud Frade, 2007, p.107)

[...] a participação na celebração tem um duplo sentido: é uma meta e um meio. Meta, porque a sua intenção é a de conduzir os fiéis à consciência do seu próprio cristianismo, vivido, fomentado, incrementado com uma vida de fé que tenha como eixo a eucaristia. [...] Meio, porque com a participação na celebração, os fiéis reunidos pelo Espírito, podem voltar-se para Deus como seu povo, como Igreja, de modo não abstrato, mas concreto: rezando juntos, cantando com “um só coração e uma só alma" [...].

A participação ativa dos fiéis na liturgia, tendo as primeiras comunidades cristãs como modelo, instituíram o que assim se passou a chamar uma volta "às fontes", isto é, redescobrir as riquezas espirituais, doutrinárias e litúrgicas do primeiro milênio do cristianismo. Esse retorno ad fonts compreendeu um olhar à tradição que influenciou sobremaneira as artes plásticas e as representações do Cristo, de Nossa Senhora, dos santos e o espaço do culto. Nesse sentido, o evento renovador do Concílio Ecumênico Vaticano II marcou o século XX deixando ricos princípios teológicos para a compreensão da funcionalidade do es- 
paço litúrgico e como ele deve ser pensado/projetado. Segundo Cardita (2018) a grande conquista da reforma litúrgica consistiu em favorecer o surgimento de formas rituais inculturadas, abertas ao gênio dos povos (cf. SC 37) e sensível à arte (cf. SC 112, 123).

No Vaticano II finalmente se mostrou como a dimensão social do ato de culto estava intimamente unida à dimensão mistérico-simbólica que, por sua vez, se relaciona com a dimensão participativa da comunidade de forma consciente e ativa (Lopez Arias, 2019, p.13). A visão transmitida pelos padres conciliares no documento sobre a Liturgia - Sacrosanctum Concilium 14 - faz ver que a fonte do espírito cristão não é simplesmente a celebração ritual da liturgia, mas sua fonte primeira é a participação ativa, plena e consciente na liturgia (Cardita, 2018, p.51). Parece-nos bem apropriado, portanto, abordar as questões levantadas naquele evento a partir desta preocupação em favorecer a participação como uma contribuição para um melhor entendimento das reformas pelas quais o espaço cultual vem passando não só no Brasil,${ }^{6}$ mas em todo o mundo, sobretudo na Europa.

Para Claudio Pastro (1948-2016), artista sacro e autor da última reforma no espaço litúrgico da Igreja São José de Anchieta, do Pateo do Collegio, o Concílio Ecumênico Vaticano II foi a fonte em que bebeu e foi educado para o desenvolvimento de seu trabalho em arte sacra por 40 anos. Assim ele o definia:

Uma volta às fontes - Ad fonts. Esse era o leitmotiv que se ouvia antes, durante e após o Concílio Ecumênico Vaticano II, na década de 1960.

[...] Ao mesmo tempo que a Igreja parecia fechar-se sobre si mesma, em pleno final do século XIX, movimentos internos e intensos, como o surgimento de congregações religiosas de cunho educativo e social, a afirmação de um monarquismo profundo e os movimentos bíblico-teológicos, mais o movimento litúrgico da primeira metade do século XX começavam a exigir "uma volta às fontes". (Pastro, 2001, p.12)

\section{História concisa da fundação do Colégio de São Paulo de Piratininga}

A origem da cidade de São Paulo está intimamente ligada à fundação do Colégio de São Paulo de Piratininga, em 1554, pela Companhia de Jesus. Em 25 de janeiro do mesmo ano aconteceu a missa inaugural celebrada pelos padres Manuel de Paiva e Afonso Brás, com a presença do irmão José de Anchieta, entre outros. Encontrando um local propício para estabelecer o colégio, um planalto, em cima de uma colina, rodeado pelos rios Tamanduateí ${ }^{7}$ e Anhangabaú, ${ }^{8}$ com um clima ameno e tendo boa visão das terras adjacentes, a ordem dos padres jesuítas empreendeu a grande aventura de estabelecer-se nesse local onde se originou a maior metrópole brasileira.

Esse episódio da fundação da cidade, muitas vezes esquecido, traz uma carga histórica relevante. São Paulo é a única cidade, que se tem notícia, que nasceu a partir de uma instituição de ensino religiosa. "Com a intenção de en- 
sinar e catequizar os indígenas que viviam neste planalto de Piratininga, os jesuítas constroem a primeira escola, feita de pau a pique (técnica de construção com barro, bambu e palha)", 9 com 14 passos de comprimento e 10 de largura (Figura 1).

Em 1556, com o crescimento do vilarejo, foram construídas uma escola e uma igreja (Figura 2) em taipa de pilão ${ }^{10}$ pelo Pe. Afonso Brás, auxiliado por uma equipe liderada pelo líder indígena Tibiriçá, ${ }^{11}$ primeiro nativo convertido e batizado na fé cristã. Segundo Costa (2010, p.127), "enquanto na Europa a Companhia se associava à exuberância das construções barrocas, aqui, suas intervenções eram marcadas por uma profunda sobriedade, não obstante deixando entrever um 'sabor popular', que desfigurava desde sempre os padrões eruditos, configurando-se como experiências legítimas de recriações".

As muitas retaliações que sofreu a Companhia de Jesus justificavam-se, sobretudo, por sua conduta em defesa da liberdade dos indígenas. Em 1640, os jesuítas foram expulsos pela primeira vez pelos bandeirantes que, explorando violentamente as terras onde se instalaram os colégios da Companhia, desejavam escravizar os nativos. Foram 13 anos de afastamento que favoreceu grandes danos aos edifícios contruídos pelos padres. Outros episódios que envolveram questões de cunho político, econômico, ideológico e cultural foram responsáveis pela descaracterização do edifício do Pateo do Collegio e pelo destino da Companhia de Jesus no Brasil. O mais sombrio foi o de 1759, quando da expulsão da Companhia de todas as colônias portuguesas por ordem do Governo Português que confiscou todos os seus bens e "a melhor construção da vila" (Fortunato, 2015, p.129) foi entregue ao poder público transformando-se em sede do Palácio dos Governadores, momento em que recebeu inúmeras reformas para adaptação do espaço ao novo uso. À fachada foram acrescentados elementos neoclássicos, contrastando com a sobriedade do estilo jesuítico, de "acordo com o gosto e a necessidade do governo em exercício, desconfigurando-a" (ibidem, p.129).

Ainda abrigando um órgão público, em 1896, o edifício foi totalmente demolido a partir de um acordo feito entre o Bispado de São Paulo, que administrava os bens da Companhia desde sua expulsão, e o Governo da Província. A decisão de demolir, e não reconstruir o templo, foi tomada após parte do teto do edifício da igreja ter desabado devido a uma forte tempestade. O altar-mor (Figura 3) foi levado para a Igreja do Imaculado Coração de Maria, localizada na Rua Jaguaribe, no bairro de Higienópolis, em São Paulo, pertencente à Congregação dos Missionários Claretianos ${ }^{12}$ e precisou ser adaptado ao espaço menor que lhe foi destinado, sendo que várias partes se perderam porque não puderam ser instaladas.

O retorno da Companhia de Jesus ao Brasil deu-se paulatinamente a partir de 1843. Na cidade de São Paulo, os bens que pertenciam à Companhia só foram restituídos em 21 de janeiro de 1954 por ocasião das comemorações do IV 


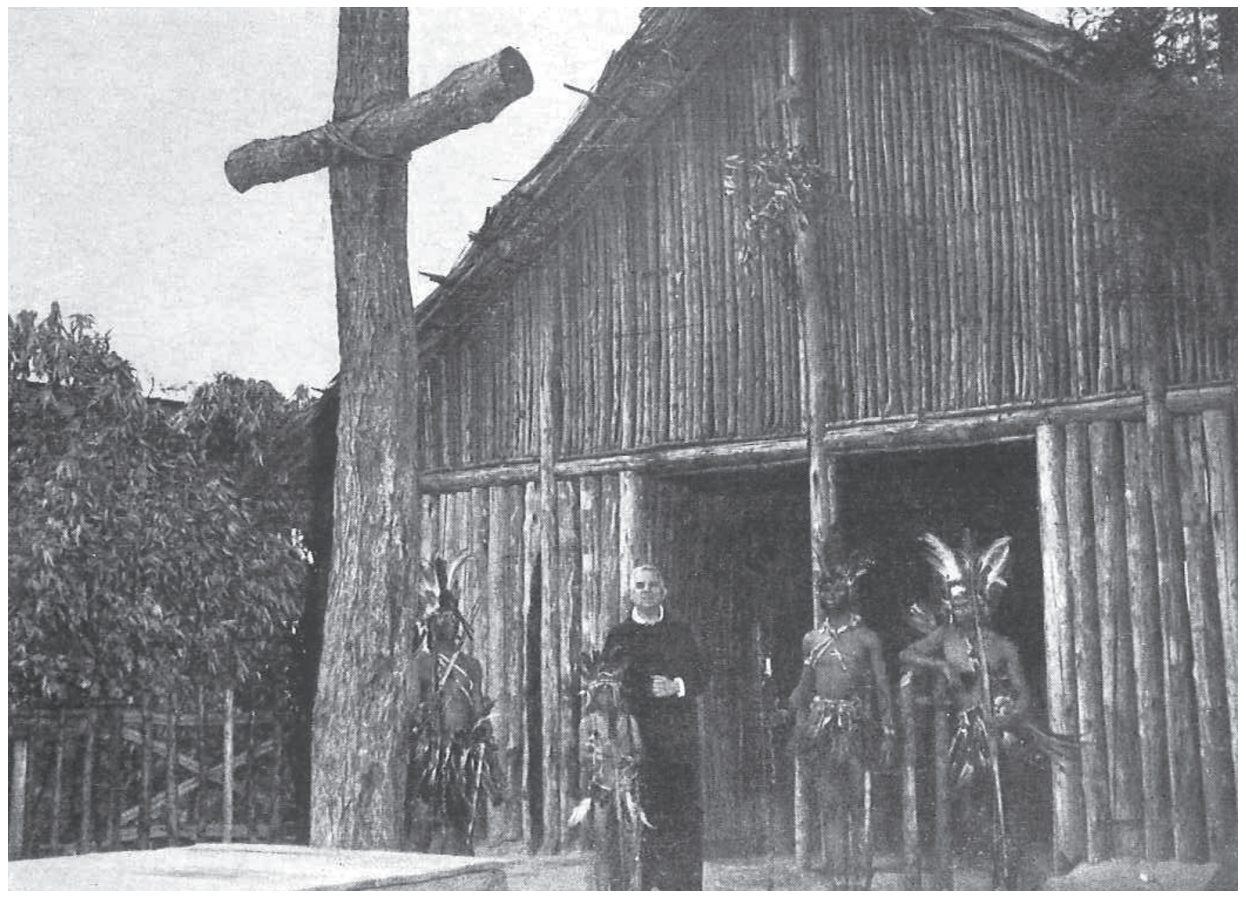

Fonte: Arquivo Pateo do Collegio.

Figura 1 - Cabana de pau a pique. Local do atual Pateo do Collegio.

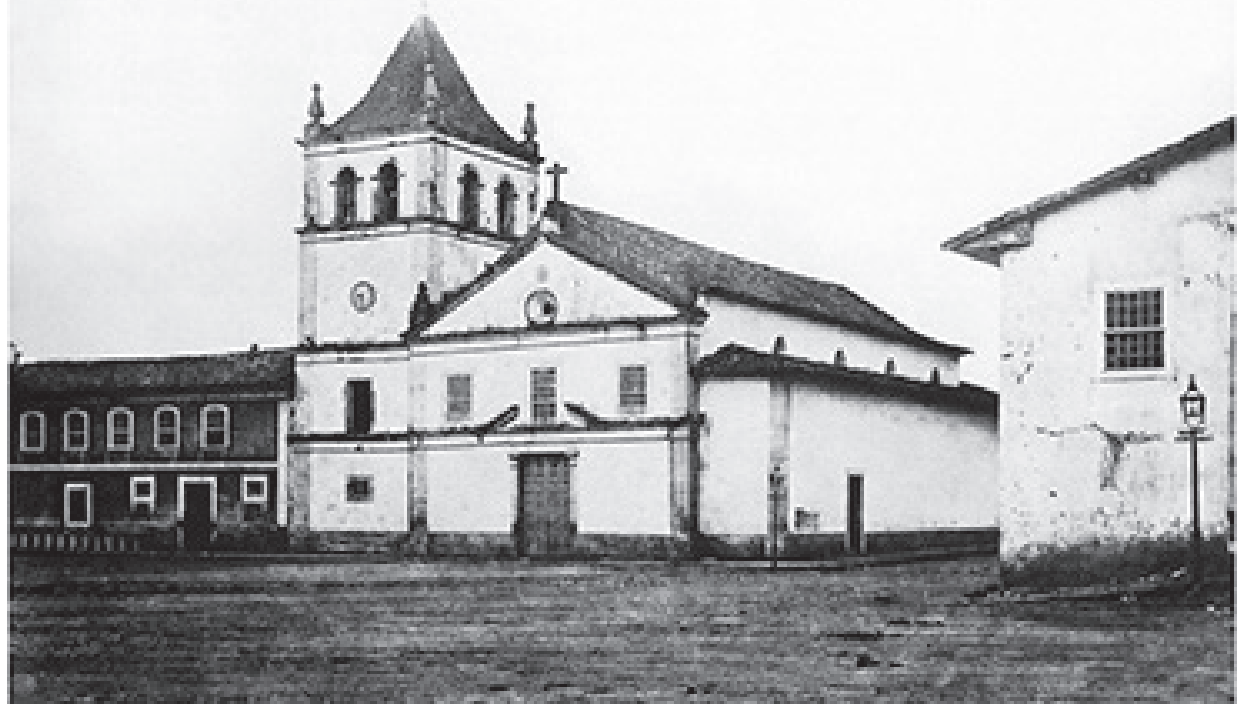

Fonte: Foto de Militão Augusto de Azevedo. Disponível em: https://saopaulopassado. wordpress.com. Acesso em: 14 mai. 2020.

Figura 2 - Pátio do Colégio - Igreja demolida. 


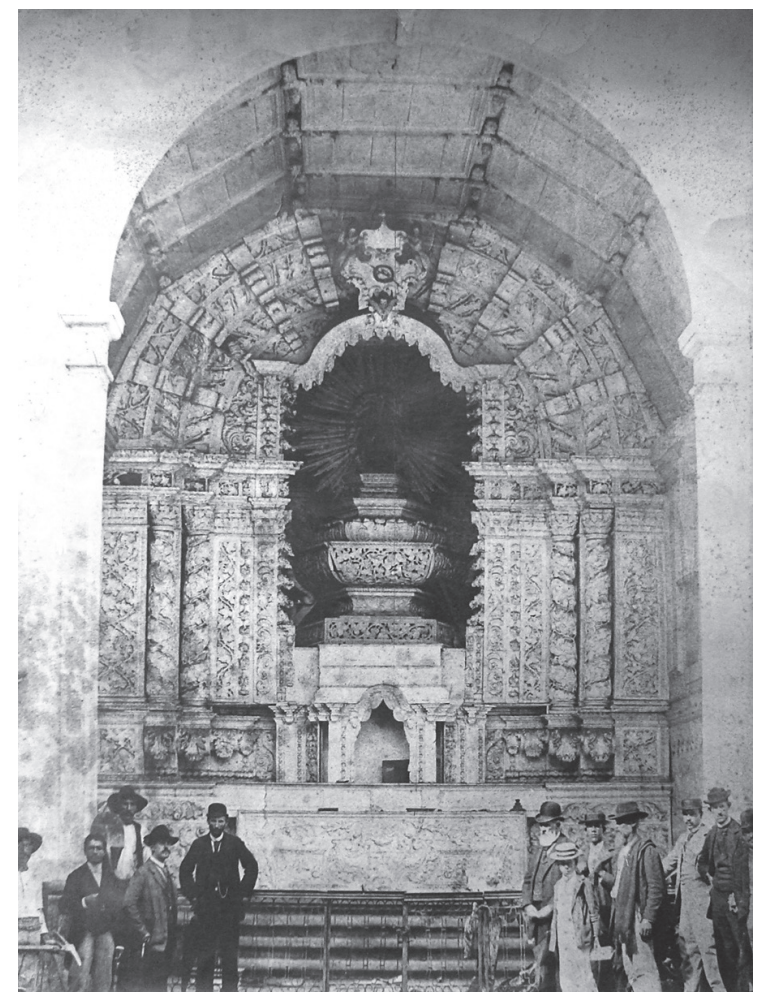

Fonte: Arquivo Pateo do Collegio.

Figura 3 - Altar-mor.

Centenário da cidade pelo então governador Lucas Garcez. O primeiro artigo da lei impôs à "Companhia as obrigações de construir um Colégio e Igreja, 'casa de Anchieta', onde seria organizado um Museu Colonial, manutenção de cursos gratuitos e atividades culturais e conservação das relíquias remanescentes da construção anterior (parede de taipa, cripta)". ${ }^{13}$

Após um período de mais de duas décadas, em 1979, o edifício, como conhecemos hoje (Figura 4), é inaugurado com uma missa comemorativa. O antigo altar-mor foi readaptado ao espaço, porém não havia mais a integralidade do conjunto. O presbitério permaneceu assim até 2009 , quando uma nova proposta de adaptação foi requerida pelos superiores da Companhia de Jesus, nas pessoas dos provinciais Pe. Carlos Palacios e do diretor do Pateo do Collegio, Pe. Carlos Alberto Contieri.

\section{A reforma do espaço litúrgico em 2009}

Claudio Pastro encontrou a Igreja São José de Anchieta conforme sua última recuperação em 1979. O conhecimento dos fatos que envolveram o primeiro edifício construído pela Companhia de Jesus em São Paulo foi a fonte primária do artista designado para fazer as reformas litúrgicas no espaço interno da igreja. Ao ser solicitado para a reforma, seguiu um caminho que não era diferente dos princípios que adotava em outras reformas do edifício cristão. As deci- 


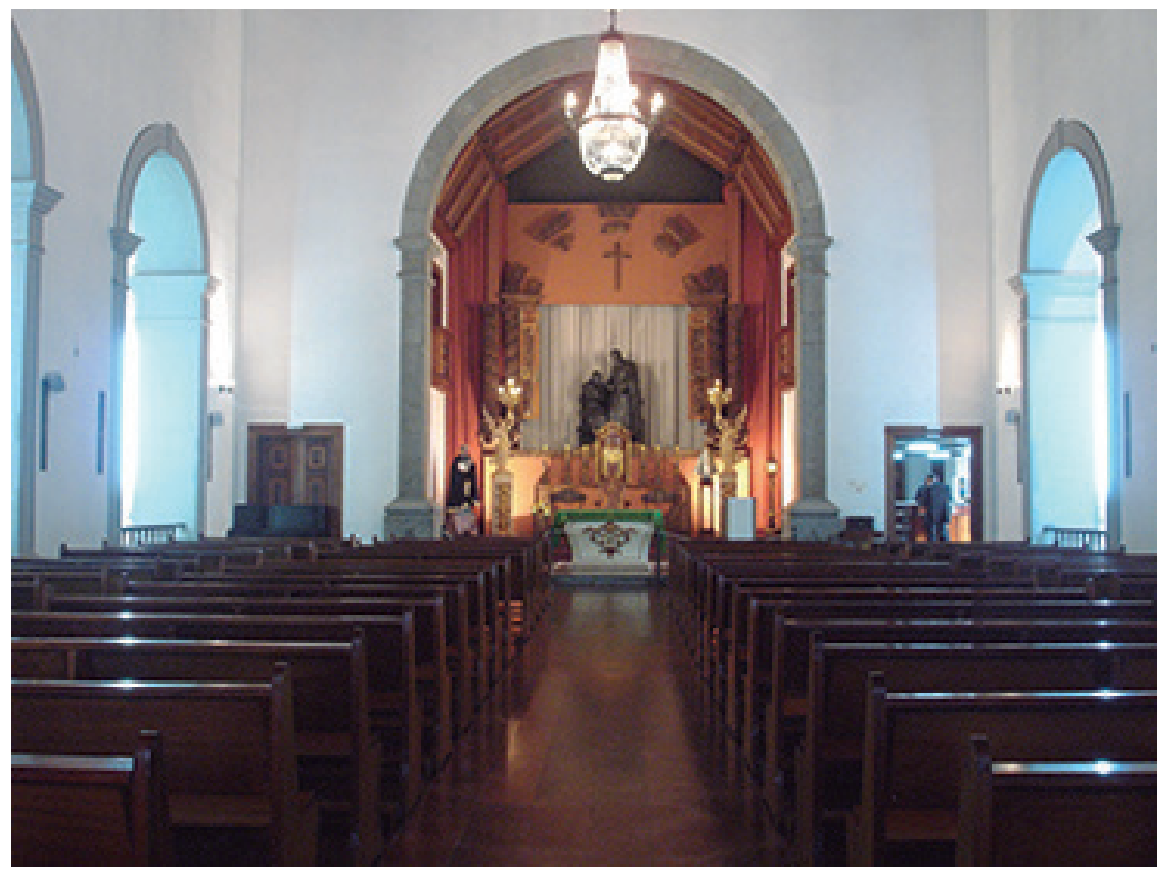

Fonte: Arquivo Pateo do Collegio.

Figura 4 - Presbitério antes da reforma - 1979.

sões tomadas estavam fundamentadas na riqueza cultural e histórica do patrimônio e deveriam seguir os princípios teológicos sobre o espaço litúrgico no espírito do Vaticano II. O mapa iconográfico do espaço sagrado deveria ser orientado a favorecer a descoberta do sentido do que se crê e propiciar a participação dos fiéis (Fernandes, 2015).

A liturgia é o cerne da vida espiritual da Igreja católica. Para Casel (2009, p.73) "a humanidade, a comunidade humana, sempre experimenta uma necessidade de vida nova, e eis por que essa epifania e essa ação redentora e salvífica se renovam indefinidamente no culto". A liturgia é solenidade ritual e simbólica em que todo gesto e toda matéria estão intrinsecamente ligados ao rito. Por meio do visível, dos objetos sensíveis da criação, tem-se acesso ao invisível: "sob o véu do símbolo eles revelam a divindade, a causa exemplar e primeira de todas as coisas, cuja natureza transcendente ultrapassa a inteligência e a linguagem humanas" (ibidem, p.75).

O sentido da liturgia não é proceder a exercícios morais, ela não tem uma finalidade prática em que o ser humano deva reagir com seus atos de virtudes, mas é, sobretudo, um veículo para colocar a alma humana em contato com o transcendente, permitindo expandir-se diante das realidades sagradas. Guardini (2018, p.57) compara a ação litúrgica a uma brincadeira infantil e à produção artística. Ambas não têm a intenção de "produzir" algo que sirva a um fim imediato, mas são maneiras que a criança e o artista encontram para expressarem-se sem ser por palavras. 
O mesmo se dá com a liturgia. Também ela, com um zelo infinito, com toda a seriedade da Criança e toda a estrita consciência do Artista, procurou exprimir em mil formas a vida da alma, vida santa nascida de Deus, não tendo outro fim senão dar-lhe o ambiente onde ela possa viver e existir.

[...] Viver a liturgia é, levado pela Graça e guiado pela Igreja, ser uma obra de arte viva diante de Deus, não tendo nenhum outro fim senão estar e viver na sua presença. (Guardini, 2018, p.68)

Para Pastro, o conhecimento do Movimento Litúrgico, sobretudo do teólogo Romano Guardini (1885-1968), e o contato com os outros teólogos mais proeminentes do Vaticano II, conduziu sua vida e sua obra apoiando-o e inspirando-o nos novos ares propostos pelo Concílio. Seu trabalho, sempre voltado à arte sacra, quis disseminar tanto nas formas pintadas ou esculpidas, assim como nos objetos de culto e nas reformas dos espaços celebrativos, o espírito que a Igreja, a partir do Concílio Vaticano II, propagou. Assim sendo, a pedido dos superiores da Companhia de Jesus, Pastro procedeu a reforma interna da Igreja São José de Anchieta. Segundo seu próprio relato, colhido pela autora (Souto, 2015), foram essas as etapas determinantes para o procedimento das alterações realizadas no presbitério e nas naves:

A convite do Pe. Carlos Palacios, provincial dos jesuítas no Brasil, e do diretor do Pateo do Collegio, Pe. Carlos Alberto Contieri para reformulação do espaço litúrgico interno segundo os princípios do Concílio Vaticano II e apreciação dos trabalhos do próprio artista.

Buscando as origens históricas do Pateo do Collegio, o artista se preocupou em recuperar os aspectos estéticos sem violar o que já fazia parte integrante do edifício.

Após estudos e pesquisas, o artista descobriu que o edifício original já havia desaparecido e o atual é uma réplica, refeita pelo Poder Público nos anos 60 e 70 do século XX. Assim sendo, o artista respeitou todo o estilo e interferiu o menos possível neste espaço.

Após reuniões com as partes interessadas, foram executadas peças litúrgicas como: altar, ambão, fonte batismal em granito rosa brasileiro e azulejaria, segundo tradição colonial ibérica, sobre a história dos jesuítas e a fundação da cidade de São Paulo.

Tratou-se, primeiramente, da "limpeza" do espaço no sentido de permitir que só o essencial se destacasse. Ao fundo um arco com azulejos dourados recorda o esplendor do antigo barroco. À frente, sédia e altar em granito maciço. Nas laterais ambão e batistério com o mesmo granito, e nos arcos laterais painéis em azulejos com a história do Pe. Manuel da Nóbrega e do Irmão José de Anchieta.

A ênfase maior desse relato recai sobre a "reformulação do espaço litúrgico interno segundo os princípios do Concílio Vaticano II", pedido claramente explicitado como o principal objetivo dos superiores da Companhia de Jesus para uma reforma "atual" da igreja. 
O espaço celebrativo é vivo, não está engessado pois dele participa uma comunidade vivente. Reformas litúrgicas já se realizaram em vários países europeus em vista da adaptabilidade desse espaço ao rito atual sem, contudo, perder seu sentido e significado mais profundo, ou seja, um lugar propício para estar e viver na presença de Deus.

A natureza do culto determina, então, os materiais que devem ser utilizados para compor o espaço. Plástico e outros materiais derivados não correspondem à nobre mensagem, tampouco os excessos favorecem o ato religioso. Não por acaso os materiais empregados por Pastro na reforma do espaço da Igreja São José de Anchieta são materiais nobres, duráveis e estáveis pois querem materializar o que a Palavra proclama.

Frade explicita o que pode acarretar a falta de entendimento do que venha a ser o lugar do culto cristão. O "tanto faz", aliado ao desconhecimento, conduz a um certo descomprometimento com o rito e acarreta a informalidade de um lugar que deve ser tratado, não segundo os subjetivismos clericais ou da comunidade, mas de acordo com a nobreza da celebração.

Para além de algumas interpretações fundamentalistas, há ainda fatos tão graves quanto: muitas pessoas que participam de nossas liturgias não conseguem ver a relação entre a liturgia da Palavra e a liturgia Eucarística - e muito menos a relação destas com a sua própria vida! A coisa às vezes chega ao ponto de várias pessoas manifestarem espontaneamente que em suas comunidades não sentem falta alguma do ambão. (Frade, 2010, p.144)

Aqui está a importância de se determinar o lugar específico de cada peça dentro do espaço celebrativo. Sem dúvida, é necessário frisar que o altar, o ambão e a sédia sejam do mesmo material pois é da mesma natureza o anúncio que deles reverberam.

\section{O altar, o ambão, a sédia e a pia batismal}

Na Igreja São José de Anchieta o ambão e a sédia são de granito rosa brasileiro. O altar, especificamente, é maciço, feito do mesmo material (Figura 5 ). Esses elementos, essenciais para a realização do rito, foram dispostos de maneira que a celebração aconteça de forma a traduzir o que a liturgia conciliar propõe: clero e assembleia são partícipes do mesmo corpo eclesial, "no rito e pelas palavras dos sacerdotes e dos fiéis” (Casel, 2009, p.73), “dá-se a ação litúrgica, sacramento da unidade, onde cada membro se manifesta de forma diversa, segundo a variedade das ordens, das funções e da participação efetiva" (cf. SC n.26).

O altar, a partir dos Padres da Igreja, ${ }^{14}$ foi se tornando a simbologia do próprio Cristo por isso tem as cinco cruzes gravadas que correspondem às cinco chagas do crucificado. Esse também é o motivo pelo qual o celebrante beija o altar no começo e no final da celebração: é o próprio Cristo que está beijando, e, como escreve Pedro (1Pd 2,4-5), Ele é a pedra viva rejeitada pelos homens. Outra justificação está no Novo Testamento, em 1Cor 10, 1b-4: “Todos atravessaram o mar e, na nuvem e no mar, todos foram batizados em Moisés. Todos 


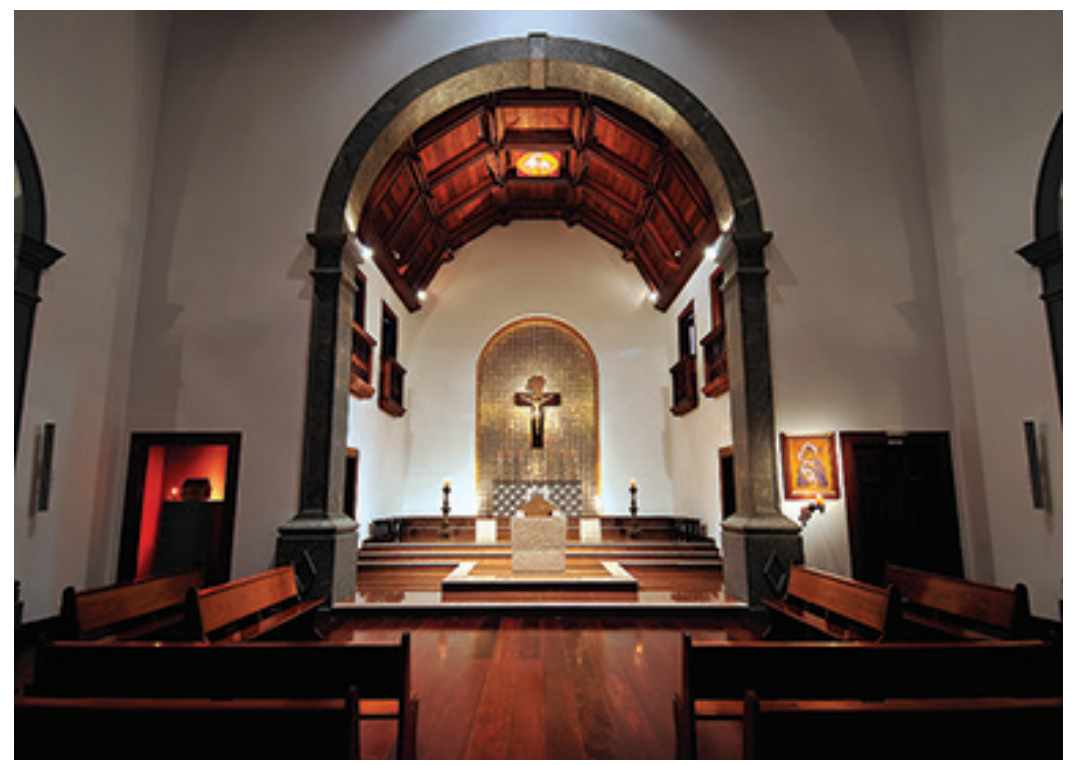

Fonte: Foto de Fábio Nunes.

Figura 5 - Presbitério depois da reforma, 2009.

comeram o mesmo alimento espiritual, e todos beberam a mesma bebida espiritual, pois bebiam de uma rocha espiritual que os acompanhava, e essa rocha era Cristo". O altar é a "mesa do banquete eucarístico" (Pastro, 1999, p.162), a mesa da partilha. Ele deve estar disposto não tanto para ser contemplado, mas para expressar a presença d'Aquele que está invisível aos olhos, desse modo, o simbolismo do altar não é de ordem analógica, mas anagógica enquanto convite para saltar para um ulterior significado (Borobio, 2008, p.59). Os católicos orientais chamam o altar de o coração do corpo místico, lugar que bombeia o sangue e alimenta toda a comunidade cristã. O cordeiro aparece pintado e fixado no teto e é um símbolo da fé cristã. Indica o sacrifício do Cristo que é o sacerdote, a vítima e o altar.

O ambão (Figura 6), palavra que vem do verbo grego "anabáino": subir, ascender, é no recinto da igreja um ponto de referência em toda a celebração, lugar elevado para o qual se dirige espontaneamente a atenção dos fiéis quando os leitores sobem para proclamar a Palavra. Com origem no judaísmo, a leitura das Escrituras, da lei, se proclamava de um lugar específico, geralmente um lugar alto para que o leitor pudesse ser visto e ouvido por todos. O ambão, como lugar litúrgico fixo da proclamação da Palavra, está carregado de significados e, ao longo da história, documenta-se que foi ornado com as mais variadas expressões da arte em catedrais, basílicas e igrejas ao redor do mundo. Ele foi visto como lugar a partir do qual se manifesta a revelação de Deus por sua palavra e, portanto, um lugar de manifestação de sua vontade salvadora (Borobio, 2008, p.61). Os teólogos sublinham a analogia do ambão com o altar enquanto lugar da anamnese de Cristo (Gerhards; Kranemann, 2012). Esse caráter anamenético 
é de memória do evento de Cristo na história. O Missal Romano (cf. n.39) indica que "o ambão seja disposto de tal modo em relação à forma da igreja que os ministros possam ser vistos e ouvidos facilmente pelos fiéis".

Em algumas igrejas católicas siríacas do século VI, encontramos o lugar do ambão no bema, ou seja, no centro do edifício. Durante a missa dominical na Igreja São José de Anchieta, o celebrante sai do altar e vai em procissão até o ambão para proclamar o Evangelho, o que enfatiza que este lugar não pode ser apenas uma pequena estante, frágil, porque é dali que emana a Palavra de vida e a força dos cristãos em afirmar a ressurreição. Junto ao ambão está o círio pascal fazendo alusão à coluna de fogo que acompanhou o povo hebreu na saída do Egito (Ex. 13-21) rumo à terra prometida. O painel de azulejo atrás do ambão é o prólogo de João (Jo 1, 1-18): é uma síntese do que se desenrola ao longo de todo o livro, mas a principal afirmação é que o Logos, ou seja, a Palavra, se fez carne, é a encarnação de Cristo na história, e por Ele e para Ele todas as coisas foram feitas, desde o início da criação e perduram no tempo.

A sédia (Figura 5), ou cadeira, colocada com distinção no fundo do presbitério da Igreja São José de Anchieta, permite que o presidente da Assembleia celebrante possa ser visto por todo o povo pois ele, ao mesmo tempo que faz parte da mesma Assembleia é sinal do próprio Cristo e cabeça da Igreja (cf. Ef l, 12). O altar e o ambão formam o conjunto constitutivo do espaço celebrativo e a utilização do mesmo material, o granito rosa brasileiro, reforça a unidade entre esses elementos que são "sinais do único Cristo" (CNBB, 2013, p.27).

A fonte batismal (Figura 7), colocada no lado oposto ao ambão, permite que o rito batismal seja por imersão (geralmente para crianças pequenas) ou infusão (quando o batismo é de adulto). "O batismo sempre começa na porta da igreja ou no batistério. ${ }^{15}$ Segundo Gerhards e Kranemann (2012, p.269) o lugar do batismo é o "terceiro local anamnético no espaço litúrgico da celebração" e torna-se sinal, recordação monumental do batismo como renascimento e purificação. Logo após o Vaticano II, procurou-se colocar a fonte batismal junto ao presbitério. Numa nova construção, ou reforma, "é preferível pensar num local próprio e grande" (Pastro, 1999, p.162). Atrás da pia, um painel de azulejo com a frase do Batistério da Igreja de São João Latrão, em Roma, traz a mensagem que evoca a finalidade do espaço, isto é, o batismo gera novos cristos.

\section{O sacrário e a Mater Misericordiae}

Para o sacrário (Figura 5), ou tabernáculo, foi criado um pequeno nicho adequado ao tamanho do espaço, suficiente para ser visível por todos aos entrar na igreja. É um lugar acessível ao altar de onde deriva a reserva eucarística.

Do lado oposto está o ícone ${ }^{16}$ da Virgem (Figura 5), a Mater Misericordiae, a Mãe de Misericórdia. A figura de Maria sempre carrega o Menino Deus e jamais é apresentada só: Ela é a Téotokos, Mãe de Deus, e aparece em vários momentos evangélicos (Anunciação, Visitação, Natividade, Apresentação do Senhor no Templo, Bodas de Caná, Crucifixão...) e nunca isolada do contexto. 


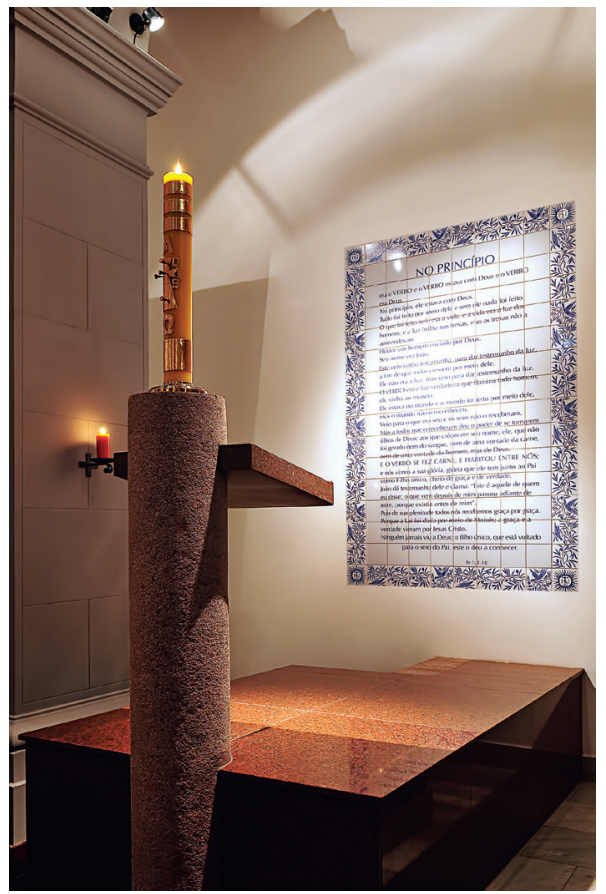

Fonte: Foto de Fábio Nunes.

Figura 6 - Ambão.

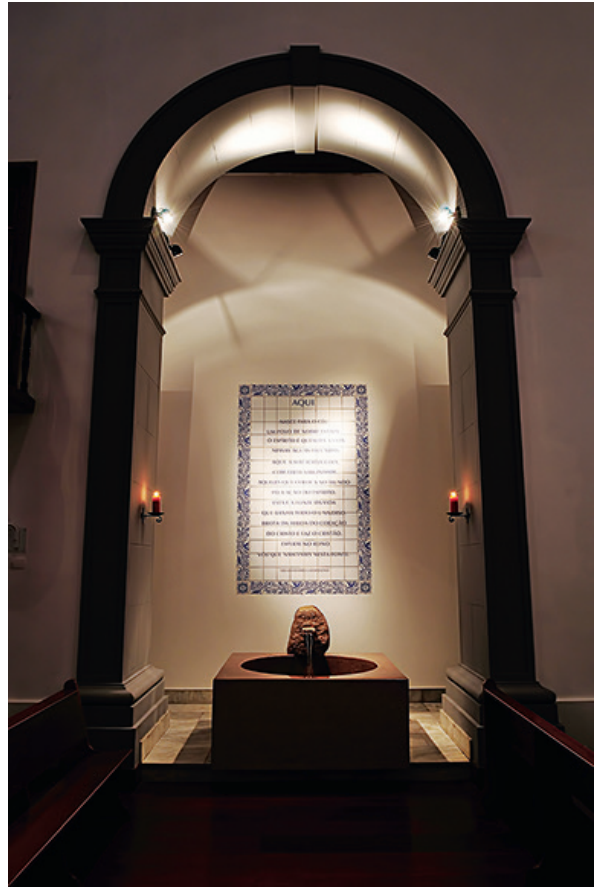

Fonte: Foto de Fábio Nunes.

Figura 7 - Fonte batismal. 


\section{Arco com azulejos}

O arco com azulejos dourados (Figura 8) no presbitério recorda o esplendor do antigo barroco. O ouro traduz a luz e o esplendor. O monograma IHSUS (do grego) é traduzido para o latim como IHS = Iesus Hominum Salvator (Jesus, Salvador dos Homens). Na logomarca transparece a história e os valores da instituição, concebidos desde o princípio por Santo Inácio de Loyola (14911556) ao optar pelo nome de Jesus como representação da Companhia.

A pequena saliência que se destaca desse grande arco dourado relembra o altar usado nas celebrações prescritas pelo Concílio de Trento, ${ }^{17}$ quando a missa era celebrada de costas para o povo. Assim como nos adornos de madeira entalhada existentes no altar-mor, antes da reforma, Pastro colocou a videira que é símbolo da comunhão da comunidade cristã.

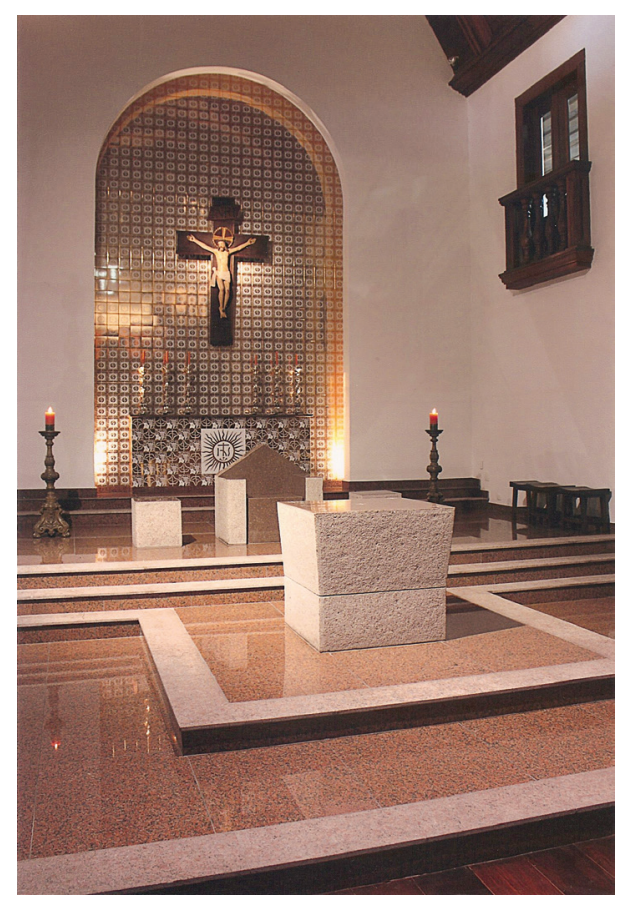

Fonte: Foto de Fábio Nunes.

Figura 8 - Arco dourado.

\section{Painéis laterais de azulejos}

O recorte histórico e teológico feito por Pastro, para a realização de quatro dos seis painéis em azulejos que se encontram na nave da igreja, contam fatos da vida de São José de Anchieta e de sua ação missionária. Não faz interpretações a respeito dos acontecimentos da vida do Santo e nem levanta questões embasadas em fatos extraordinários, mas - com essencialidade - reconta, em imagens gráficas, o que um missionário, em terras tão inóspitas, vivenciou. É o modo de vida do Irmão Anchieta, assim chamado quando chegou com 19 anos ao Brasil, que Pastro adentra com uma peculiar síntese. Dentre os atributos do 
jesuíta, o artista destaca sua desenvoltura para aprender uma língua diferente, a capacidade de relacionar-se com os nativos e com a nova terra a ser desbravada e, sobretudo, o grande amor à Eucaristia e à Virgem Maria, certamente embasados nos ensinamentos do fundador da Companhia de Jesus: Santo Inácio de Loyola. "Esse é o projeto desses homens (jesuítas) que é o projeto cristão. Ser chamado à vida é ser chamado cristão" (Pastro apud Genoveze, 2015, p.140). Nas cores azul e branca, Pastro explora a tradição dos azulejos portugueses.

\section{Anchieta e Nóbrega}

Nóbrega carrega um livro com a palavra Evangelho em latim e Anchieta está segurando a versão traduzida para a língua tupi. Sua missão é trazer a esta terra, a novidade da fé cristã. Ambos seguram uma cruz como estandarte de vitória.

Tibiriçá foi o primeiro índio a ser catequizado e batizado por Anchieta. Bartira, sua filha, casou-se com o português João Ramalho. As três figuras estão sob uma palmeira que lembra o primeiro nome indígena das terras brasileiras: Pindorama, terra das palmeiras. Anchieta está ensinando a oração do Pai Nosso em tupi guarani aos indígenas.

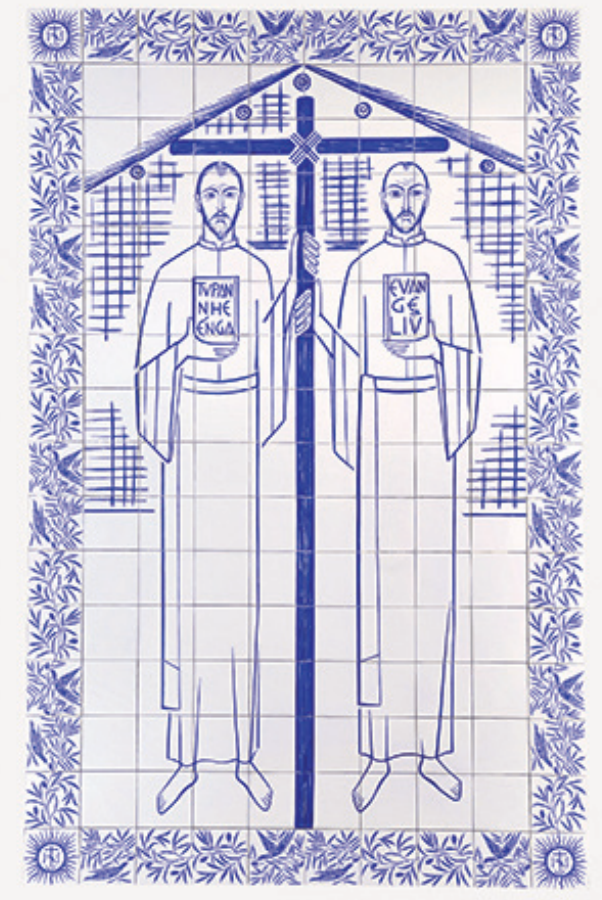

Fonte: Foto de Fábio Nunes.

Figura 9 - Anchieta e Nóbrega capela/piroga.

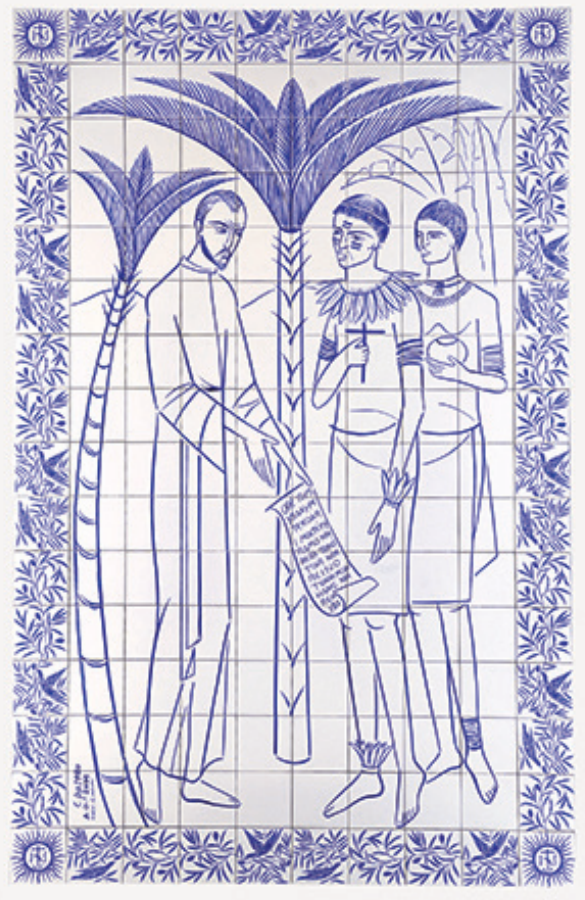

Fonte: Foto de Fábio Nunes.

Figura 10 - Anchieta e índios Tibiriçá e Bartira. 


\section{Poema à Virgem}

São José de Anchieta (1534-1597) escreve o Poema à Virgem nas areias da Praia de Iperoig, em Ubatuba. Em 1563, durante a guerra entre tamoios e tupiiquins, o religioso se fez refém e escreveu, nas areias da praia, o Poema à Virgem com mais de 5.785 versos.

\section{Anchieta e a Eucaristia}

Anchieta está ajoelhado dentro de um barco, uma piroga, com um índio e, na frente, Nóbrega carrega o ostensório com a hóstia consagrada. Sobre suas cabeças os pássaros guarás fazem sombra ao barco. Uma frase retrata a adoração de Anchieta ao corpo de Cristo no poema de sua autoria.

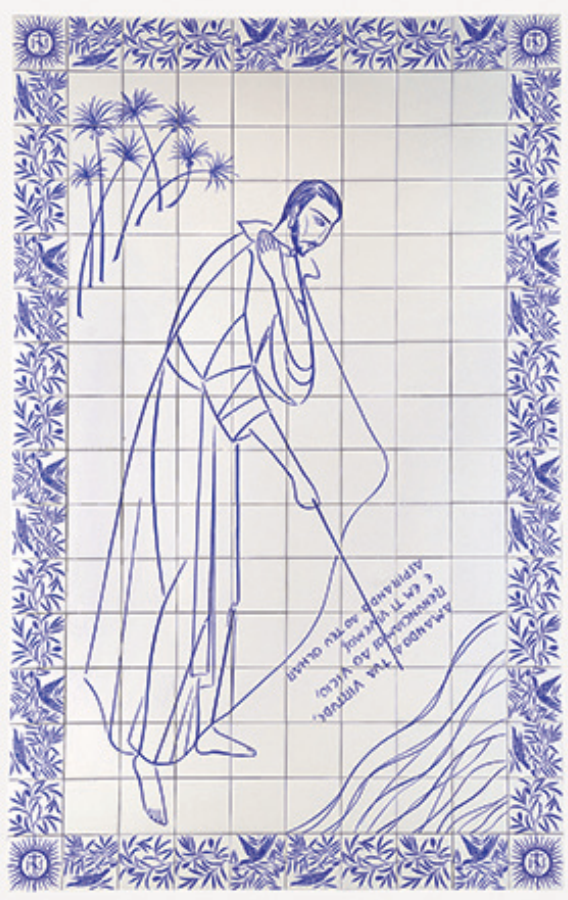

Fonte: Foto de Fábio Nunes.

Figura 11 - Poema à Virgem.

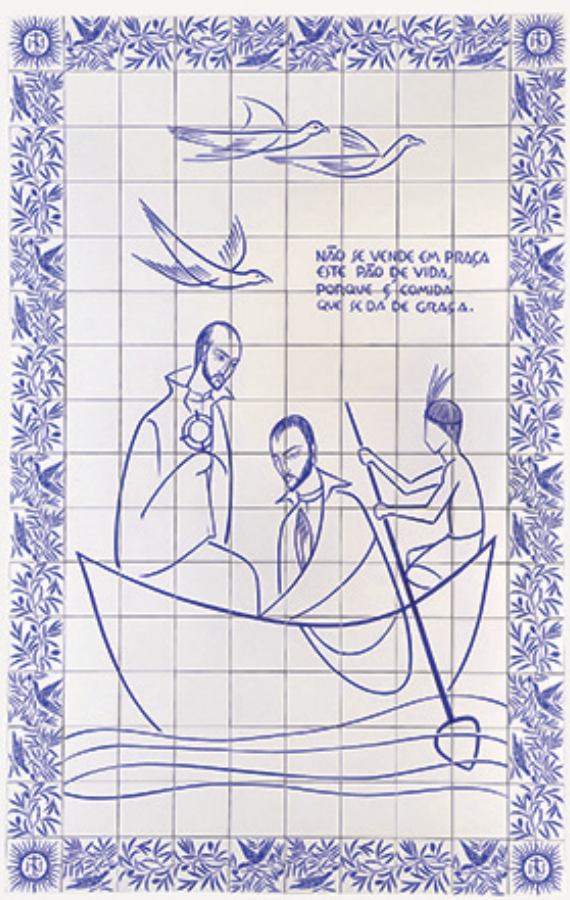

Fonte: Foto de Fábio Nunes.

Figura 12 - Anchieta e a eucaristia.

\section{Considerações finais}

As alterações efetuadas na Igreja São José de Anchieta aconteceram baseadas na tradição e nos documentos eclesiais, principalmente do Concílio Ecumênico Vaticano II. O edifício que hoje conhecemos é a terceira construção, réplica do original de 1556, e o maior interesse foi buscar a unidade entre o espaço litúrgico e o rito aí celebrado. Para que isso acontecesse, levaram-se em conta fatores históricos da tradição, dos documentos da Igreja e do passado da Companhia de Jesus. As reformas efetuadas adaptaram o espaço de maneira que haja uma visibilidade da ação litúrgica em sua totalidade, sem separações 
ou divisões, para que a comunidade viva e atuante seja o sujeito da celebração. Nesse sentido, sobressai o complexo sistema de sinais do espaço litúrgico que, na tradição da Igreja, tem funções diversas como ser mapa para aprofundar a fé, servir de espaço de comunhão e visualização daquilo que se celebra.

O trabalho de reforma realizado na Igreja São José de Anchieta segue a linha contínua da realização dos primeiros jesuítas que chegaram a São Paulo e, apesar de uma história descontinuada, o Pateo do Collegio segue como referência e marco de início da maior cidade do País, buscando cada vez mais realizar sua principal vocação: evangelizar a cultura.

\section{Notas}

1 Claudio Pastro (1948-2016), artista plástico, dedicou-se exclusivamente à arte sacra por 40 anos. Era paulistano, nascido a 15 de outubro de 1948, de uma família católica. Além da formação familiar, teve encontros decisivos na sua vida que o influenciaram definitivamente como cristão e como artista do nosso tempo. Como primícias, tinha o rigor de ir buscar as origens e tradições tanto da própria fé quanto do povo brasileiro. Pesquisou muito, apoiando-se na experiência dos Santos Padres da Igreja, na riqueza do rito oriental e nos documentos do Concílio Ecumênico Vaticano II.

2 A Companhia de Jesus, ou Ordem dos Jesuítas, como também é conhecida, foi fundada pelo basco Inácio de Loyola e aprovada oficialmente pelo Papa Paulo III, em 27 de setembro de 1540. "Os primeiros jesuítas desembarcaram no Brasil, liderados por Manuel da Nóbrega, em 1549 - apenas nove anos após a Companhia de Jesus ser aprovada pelo Papa Paulo III. Vindos com Tomé de Sousa, primeiro governador-geral do Brasil Colônia, os religiosos foram pioneiros no trabalho de educação dos descendentes de portugueses e nativos. Entre os jesuítas ilustres que atuaram aqui, estão os padres José de Anchieta e Antônio Vieira. Com marcante influência histórica e social no país, a Companhia de Jesus esteve à frente da fundação de escolas, igrejas e cidades. Os padres Manuel da Nóbrega e José de Anchieta, por exemplo, foram os responsáveis pela criação do Colégio de São Paulo de Piratininga (hoje Pateo do Collegio), que deu origem à cidade de São Paulo" (Site: jesuitasbrasil.org.br. Disponível em: <https:// www.jesuitasbrasil.org.br/institucional/quem-somos/>. Acesso em: 29 abr. 2020).

3 "Nascido a 11 de agosto de 1901 em Revensburg, Alemanha, D. Martinho havia participado de um movimento de jovens orientado por Romano Guardini, autor de um livro que se tornou célebre e foi traduzido em muitas línguas, O espirito da liturgia. O contato com o movimento de juventude e com Guardini parece ter deixado profundas marcas em Dom Martinho, preparando-o para a sua futura missão. Ingressou depois no mosteiro beneditino de Beuron, onde professou para a abadia de Neresheim. Fez os estudos de filosofia na célebre abadia de Maria Laach, onde conheceu o abade Ildefonso Herwegen e sobretudo D. Odo Casel. Cursou teologia no Colégio Santo Anselmo, em Roma, onde se doutorou. Com apenas 29 anos veio para o Brasil, em 1930, a fim de elevar o nível dos estudos teológicos da Congregação beneditina. E 1933 seria seu último ano aqui se, em junho, seu eventual substituto, D. Tomás Keller, não tivesse sido eleito abade do mosteiro do Rio de Janeiro" (Clemente Isnard, OSB, O movimento litúrgico no Brasil, in Botte, O movimento litúrgico..., 2009 apud Frade, 2007, p.109). 
4 Arcebispo emérito de Olinda e Recife, foi um dos fundadores da Conferência Nacional dos Bispos do Brasil (CNBB) e árduo defensor dos direitos humanos sobretudo durante o regime militar.

5 Pentecostes é a festa litúrgica cristã celebrada 50 dias após a Páscoa. O papa Bento XVI assim a define: "Tem início um processo de reunificação entre as partes da família humana, divididas e dispersas; as pessoas, muitas vezes, reduzidas a indivíduos em competição ou em conflito entre si, alcançadas pelo Espírito de Cristo, abrem-se à experiência da comunhão, que pode empenhá-las a ponto de fazer delas um novo organismo, um novo sujeito: a Igreja. Este é o efeito da obra de Deus: a unidade; por isso, a unidade é o sinal de reconhecimento, o 'cartão de visita' da Igreja no curso da sua história universal" (Bento XVI, Homilia na Solenidade de Pentecostes, 23 de maio 2010).

6 As instruções sobre a construção do espaço para a liturgia romana ficam a cargo das Conferências dos Bispos de cada nação e, no caso do Brasil, as orientações foram redigidas pela chamada Comissão Episcopal Pastoral para a Liturgia da CNBB, publicada em 2013, sob o título: Orientação para Projeto e Construção de Igrejas e Disposição do Espaço Celebrativo. Estudos da CNBB 106, Brasília: Edições CNBB.

7 Tamanduateí, rio dos tamanduás ou do peixe seco.

8 Anhangabaú, rio do Deus Anhangá.

9 Disponível em: <https://www.pateodocollegio.com.br/pateo-do-collegio-linha-do-tempo/>. Aceso em: 24 abr. 2020.

10 “A taipa de pilão é um sistema rudimentar de construção em que a terra é comprimida em caixas de madeira, chamadas de taipas. O barro é disposto horizontalmente em camadas de cerca de $15 \mathrm{~cm}$ de altura e socado - com piladores manuais ou socadores pneumáticos - até atingir a densidade ideal, criando uma estrutura resistente e durável". Disponível em: <https://www.archdaily.com.br/br/tag/taipa-de-pilao>. Acesso em: 29 abr. 2020.

11 Tibiriçá foi um grande aliado dos portugueses e importante figura na fundação da cidade de São Paulo juntamente com os jesuítas. Os restos mortais de Tibiriçá encontram-se na cripta da Catedral da Sé, no centro da cidade de São Paulo.

12 Congregação dos Missionários Filhos do Imaculado Coração de Maria, fundada por Santo Antônio Maria Claret em 16 de julho de 1849.

13 Disponível em: <https://www.pateodocollegio.com.br/pateo-do-collegio-linha-do-tempo/>. Acesso em: 29 abr. 2020.

14 Os Padres da Igreja foram grandes cristãos que viveram durante os oito primeiros séculos do cristianismo testemunhando a fé com seus ensinamentos coerentes com a própria vida.

15 O lugar da fonte batismal deve ser pensado em conjunto com os outros espaços, manter sempre a conexão com o espaço da celebração eucarística, mas não colocado no presbitério (cf. CNBB, 2013, p.150).

16 Termo derivado do grego eikon, imagem. Na arte pictórica religiosa, identifica uma representação sacra. O ícone é a representação, por imagens, da mensagem cristã descrita por palavras nos Evangelhos (cf. CNBB, 2013, p.79).

17 O Concílio Ecumênico de Trento foi convocado pelo papa Paulo III, em 1542, e teve início em 1545. A Reforma protestante iniciada por Lutero expandia-se pela Europa 
e a Igreja Católica precisava rever sua doutrina. A promulgação das decisões tomadas tornou-se pública somente em 1563, ou seja, o Concílio demorou 18 anos devido a várias interrupções e algumas delas ocorridas por constantes guerras.

\section{Referências}

BOROBIO, D. La dimensión estética de la liturgia: arte sagrado y espacios para la celebración. Cuadernos phase, 180. Barcelona, 2008.

BRITO, L. Reformada, igreja do Pátio do Colégio terá batismo com água quente. Disponível em: <http://gl.globo.com/Noticias/SaoPaulo/0,„MUL1337588-5605,00REFORMADA+IGREJA+DO+PATIO+DO+COLEGIO+TERA+BATISMO+COM+ AGUA+QUENTE.html>. Acesso em: 14 maio 2020.

CARDITA, A. M. dos S. Reforma litúrgica para quê??: revisitando a Sacrosanctum Concilium. São Paulo: Edições Loyola, 2018.

CASEL, O. Le mystère de l'église: union de Dieu et des hommes. Luxembourg: Maison Mame, 1965.

O mistério do culto no cristianismo. São Paulo: Edições Loyola, 2009.

CONCÍLIO VATICANO II. Constituição sobre a Sagrada Liturgia Sacrosanctum Concilium. 11.ed. São Paulo: Edições Paulinas, 2011.

CONFERÊNCIA Nacional dos Bispos do Brasil. Orientações para projeto e construção de Igrejas e disposição do Espaço Celebrativo. n.106. Edições CNBB, 2013.

COSTA, L. A arquitetura dos jesuítas no Brasil. ARS (São Paulo), São Paulo, v.8, n.16, p.127-95, 2010. Disponível em: <http://www.scielo.br/scielo. php?script=sci_arttext\&pid=S1678-53202010000200009\&lng=pt\&nrm $=$ iso $>$. Acesso em: 24 abr. 2020.

EUSÉBIO DE CESAREIA. História Eclesiástica. São Paulo: Paulus, 2000. (Coleção Patrística, 15, VIII, 2, 1).

FERNANDES, M. L. Recepção artística na América Latina. In: Dicionário do Concilio Vaticano II. São Paulo: Paulus, 2015. p.797-803.

FLORES, J. J. Introdução à teologia litúrgica. São Paulo: Paulinas, 2006.

FORTUNATO, I. Historicidade e geograficidade do Pateo do Collegio, coração do centro histórico de São Paulo. REVISTA COLETÂNEA, Rio de Janeiro, v.14, n.27, p.109-33, jan/jun 2015. Disponível em: <http://www.revistacoletanea.com.br/index. php/coletanea/article/view/39>. Acesso em: 20 maio 2020.

FRADE, G. Arquitetura Sagrada no Brasil. São Paulo: Loyola, 2007.

FRADE, G. O espaço litúrgico: o ambão, lugar da celebração da Palavra. Revista de Cultura Teológica, São Paulo, v.18, n.72, p.135-146, out.-dez. 2010. Disponível em: https://revistas.pucsp.br/index.php/culturateo/article/view/15379/11486. Acesso em: 1 set. 2021.

GENOVEZE, C. C. Os painéis de azulejos de São José de Anchieta no Pátio do Colégio de Claudio Pastro interpretados em três perspectivas: do artista, do espaço e do observador. São Bernardo do Campo, 2015. Dissertação (Mestrado em Ciências da Religião) - Universidade Metodista de São Paulo. 
GERHARDS, A.; KRANEMANN, B. Introdução à liturgia. São Paulo: Loyola, 2012.

GONZÁLEZ, M. F. Construção em taipa: 15 projetos impressionantes. Disponível em: <https://www.archdaily.com.br/br/tag/taipa-de-pilao>. Acesso em: 29 abr. 2020.

GUARDINI, R. Espírito da liturgia. São Paulo: Cultor de Livros, 2018.

LOPES ARIAS, F. Projetar o espaço sagrado: o que é e como se constrói uma igreja. Brasília: Edições CNBB, 2019.

MALDONADO, L.; FERNÁNDEZ, P. A celebração litúrgica: fenomenologia e tecnologia da celebração. In: BOROBIO, D. (Org.) A celebração na Igreja: liturgia e sacramentologia fundamental. São Paulo: Loyola, 1990. p.161-277.

PASTRO, C. Guia do espaço sagrado. Edições Loyola: São Paulo, 1999.

PASTRO, C. C. Pastro: arte sacra. São Paulo: Paulinas, 2001.

PATEO do Collegio - Linha do tempo. Pateodocollegio.com.br. 2015. Disponível em: <https://www.pateodocollegio.com.br/pateo-do-collegio-linha-do-tempo/>. Aceso em: 24 abr. 2020.

QUEM somos. Pateodocollegio.com.br. 2015. Disponível em: <https://www.pateodocollegio.com.br/tag/companhia-de-jesus/>. Acesso em: 23 abr. 2020.

RAMOS, F. de A. Danilo Mondoni. Os expulsos voltaram. Os jesuítas novamente no Brasil (1842-1874). Lumen Veritatis - Revista tomista|Filosofia Teologia - Tomás de Aquino, v.7, n.28, p.378-81, out. 2017. Disponível em: <http://lumenveritatis.org/ ojs/index.php/lv/article/view/397>. Acesso em: 29 abr. 2020.

SOUTO, H. A reforma do Pateo do Collegio. Arquivo da Abadia Nossa Senhora da Paz, Itapecerica da Serra, mai. 2015. Depoimento concedido à Hilda Souto.

RESUMO - A origem da cidade de São Paulo está intimamente ligada à fundação do Colégio de São Paulo de Piratininga, em 1554, pela Companhia de Jesus. Em 25 de janeiro desse mesmo ano, aconteceu a missa inaugural celebrada pelos padres Manuel de Paiva e Afonso Brás, com a presença do irmão José de Anchieta, entre outros. Do ano de sua fundação, pela Companhia de Jesus, até hoje, muitas foram as modificações sofridas no complexo arquitetônico original. Inúmeras situações desfavoráveis, tanto políticas quanto religiosas, poderiam ter relegado ao esquecimento uma origem tão singular e tão importante não só no âmbito espiritual, mas também educacional de São Paulo, porém esse lugar permanece como um marco da história da Companhia de Jesus e do seu legado arquitetônico e artístico à cidade. O presente artigo pretende expor alguns dados primordiais da história do Pateo do Collegio para contextualizar as mudanças do projeto iconográfico interno ocorridas no ano de 2009, elaborado pelo artista sacro, Cláudio Pastro (1948-2016), que, a pedido dos superiores da instituição, empreendeu a reforma do espaço litúrgico com base nos documentos da Igreja Católica à luz do Concílio Ecumênico Vaticano II.

Palavras-Chave: Cláudio Pastro, Pateo do Collegio, Jesuíta, São Paulo, Liturgia.

ABSTRACT - The origin of the city of São Paulo is deeply connected to the establishment of the São Paulo de Piratininga School in 1554 by the Society of Jesus. The inaugural Mass took place that year, on January 25 th, celebrated by Father Manuel de Paiva and 
Father Afonso Brás, who was José de Anchieta’s brother, among others. Since its establishment, the original architectural complex of the Pateo do Collegio underwent many changes. Numerous unfavorable situations, both political and religious, might have led to the oblivion of this important and unique origin, yet the place remains a landmark in the Society of Jesus's history and in the city's architecture legacy. Its importance goes beyond the spiritual sphere, as it is also is educationally significant in São Paulo. This article intends to portray some primordial data about the Pateo do Collegio's history to contextualize the changes made in the internal iconographic project in 2009 by artist Claudio Pastro (1948-2016), who, answering to a request from the institution's superiors, refurbished the liturgical space according to Catholic Church's documents inspired by Second Vatican Council.

KErWords: Cláudio Patro, Pateo do Collegio, Jesuit, São Paulo, Liturgy.

Hilda Souto é doutoranda em Teologia pela Pontifícia Universidade Católica do Paraná, mestre em Artes Visuais pela Universidade Estadual Paulista (Unesp) e graduada em Licenciatura em Artes Plásticas pela Fundação Armando Álvares Penteado (SP). Atua como professora, artista plástica e designer. @ - hildasouto.arte@gmail.com / https://orcid.org/0000-0001-6101-8800.

Márcio Luiz Fernandes é professor adjunto no Programa de Pós-Graduação em Teologia da Pontifícia Universidade Católica do Paraná e da Faculdade Claretiana Studium Theologicum. Doutor em psicologia pela Universidade de São Paulo, mestre em Teologia Fundamental pela Pontifícia Universidade Lateranense e pós-doutor em Psicologia pela Universidade de São Paulo. @- marciovisconde@yahoo.com.br / https://orcid.org/0000-0002-0944-1676.

Recebido em 15.5.2020 e aceito em 5.3.2021.

I, II Pontifícia Universidade Católica, Programa de Pós-Graduação em Teologia, Curitiba, Paraná, Brasil. 
